\title{
COMPARABLE WORTH: A LEGAL AND PROFESSIONAL UPDATE
}

\author{
C. Ray Gullett \\ College of Business Administration \\ The University of Texas at Tyler \\ Tyler, Texas
}

It is well known that women as a class of workers earn less than men. Women's wages average approximately two-thirds of what male workers earn. During the last twenty years this proportion has changed very little [13] although some narrowing of the gap has occurred since 1979. It is also common knowledge that women are clustered in a relatively small number of occupational categories. In 1981 about seventy-five percent of women workers were employed in six broad categories ([21], p. 54): clerical workers; service workers; educators, librarians, and social workers; sales clerks; nurses and health technicians; clothing and textile workers. In summary, women in general earn less than men and are crowded into a relatively small number of occupations.

Of course these macro statistics do not tell the entire story. Variations by such categories as age, job grouping, location, education, and seniority provide differing results. For an employee the most important wage relationships are in his or her own firm. This is mainly where the individual worker experiences pay equity or inequity.

And, as the great volume of publicity in the last few years suggests ([2], [6], [20]), many women in the workforce do believe that they are underpaid for the work they do. Much of this underpayment is blamed on sex discrimination.

\section{Equal Pay Act of 1963}

It is generally agreed [22] that "equal pay for substantially equal work" has been largely achieved through the enforcement of the Equal Pay Act of 1963 [24]. This law prevents employers from paying men more than women who do essentially the same work. Thus an employer cannot arbitrarily decide to pay female bank tellers less than male bank tellers simply because of their sex.

The law does not require that jobs be identical to be covered. Only substantial equality is necessary. Neither slight differences in duties nor different job titles create an exception.

Equality among jobs is measured by their similarity of skill, effort, responsibility, and working conditions. Exemptions to the laws include pay differences based on bona-fide merit systems, incentive plans, seniority systems, or any other factor other than sex. 


\section{Limitations of EPA Coverage}

While the Equal Pay Act has reduced pay discrimination in the workplace, it is limited in its application. As stated above, the Act deals only with discrimination in pay among jobs which are substantially the same in content. It cannot be used to make pay comparisons among jobs which are very different. Thus a women clerical worker cannot successfully claim pay discrimination under this law because her salary is less than that of a male maintenance worker. The two jobs do not meet the "substantial equality" test under EPA and cannot be compared for purposes of this law.

Critics of pay practices in government and industry ([2], [4], [19]), have, however, contended that many jobs which are traditionally held by women are undervalued in the marketplace when compared with jobs traditionally held by men. Nurses, for example, are commonly paid less than truck drivers; public schoolteachers earn less than skilled craft workers. Some critics ([2], [19]) also contend that job evaluation systems used in many firms are designed that "men's jobs" receive a higher rating than jobs which are typically held by women.

\section{Comparable Worth Defined}

These criticisms of pay practices fall under the heading of an approach to pay called comparable worth. Jobs are said to be comparable when: (a) they have substantially different duties, but (b) are rated as having approximately equal value by an "objective" job evaluation plan. Because they are comparable, it is argued that they should be paid the same even when the average market rates for the jobs differ.

\section{Title VII of the Civil Rights Act of 1964 and Comparable Worth}

Because the Equal Pay Act does not cover cases of comparable worth, advocates of reform in pay structures have sought relief under Title VII of the Civil Rights Act of 1964 (as amended) [25]. This law is "broad brush" legislation which prohibits discrimination in the workplace based on race, religion, sex, or national origin. It applies to such employment functions as selection, promotion, and termination of employees. But does it apply to compensation practices which may be discriminatory but are not covered by the EPA?

Due to the wording of Title VII, there was uncertainty for many years regarding coverage ([15], [18]). In 1981 the Supreme Court answered this question in its often-cited Gunther decision [7]. Essentially, the Court said that Title VII allows persons to file charges of sex-based pay discrimination where there is no EPA violation. But the Court was careful to state that its ruling in the Gunther case did not explicitly deal with comparable worth. Gunther opened the door for such charges to be filed, but the Court did not reveal how it might rule. 
Both before and after the Gunther decision federal courts have heard pay equity cases charging Title VII discrimination. Not all of these decisions are in agreement with each other. This is in part because of the differences in the facts of each case. Additionally, judges vary in their views toward pay comparability. However, the courts have agreed that a crucial factor in finding a Title VII violation is intent to discriminate against women with regard to pay.

For example [17], the deliberate segregation of women into lower paying jobs and men into higher paying ones is a Title VII violation although not a comparable worth situation. Similarly, the Gunther case involved a decision to pay women less than the market-surveyed rate. This decision was based on an employer belief that at least some women would work for less than the average "going rate." Again, the employer lost the case.

\section{Comparable Worth Cases}

The more difficult cases are those involving conflicts between the internally evaluated worth of jobs and their average of "going rate" in the marketplace. These are true comparable worth cases. In these situations the employer has measured a group of jobs with the same internal job evaluation plan. Although different in content, some of the predominantly female jobs are ranked equal in value to some predominantly male jobs. However, the male jobs have higher market rates than their female counterparts. When the employer has chosen to pay the market differential rates for these jobs, comparable worth discrimination has been charged.

Not all federal courts have sided with employers on this type of case. No federal appeals court, however, has ruled against an employer in such a case. In general, discriminatory intent has not been found ([1], [3], [5], [9]) where the employer has chosen to follow market rates for jobs internally rated as comparable although dissimilar in content. Pay inequities caused by different market rates were not ruled to be intentional discrimination.

In short, at the federal level the comparable worth concept shows little legal vitality. While the Supreme Court has not yet ruled on the issue, it may have already signaled its position when it refused to hear a ninth circuit decision [16] denying a comparable worth claim. The current status of pay equity claims is outlined in Figure 1.

A number of states have passed some form of comparable worth legislation. Frequently these laws apply only to public sector employees. Many are worded so vaguely that court tests are needed to define their impact on the private sector.

\section{Comparable Worth and Collective Bargaining}

Another method for obtaining comparable worth may be through the collective bargaining process. However, union support for this concept has not been uniform. 
Are men and women performing

substantially equal work in the same enterprise and being paid different rates?

Are men and women being hired for the same or substantially equal work but being hired at different rates because the employer believes women will work for less?

Are women kept in segregated departments and thus prevented from movement into higher paying male-dominated jobs?

Has the employer made market surveys of "going rates" for jobs? Has the employer chosen to pay average market rates for male dominated jobs and less than average market rates for female-dominated jobs?

Has the employer rated dissimilar jobs as approximately equal in terms of an internal job evaluation plan? Has he chosen to pay male-dominated jobs more than comparable female-dominated jobs because of differences in market rates shown in market surveys?
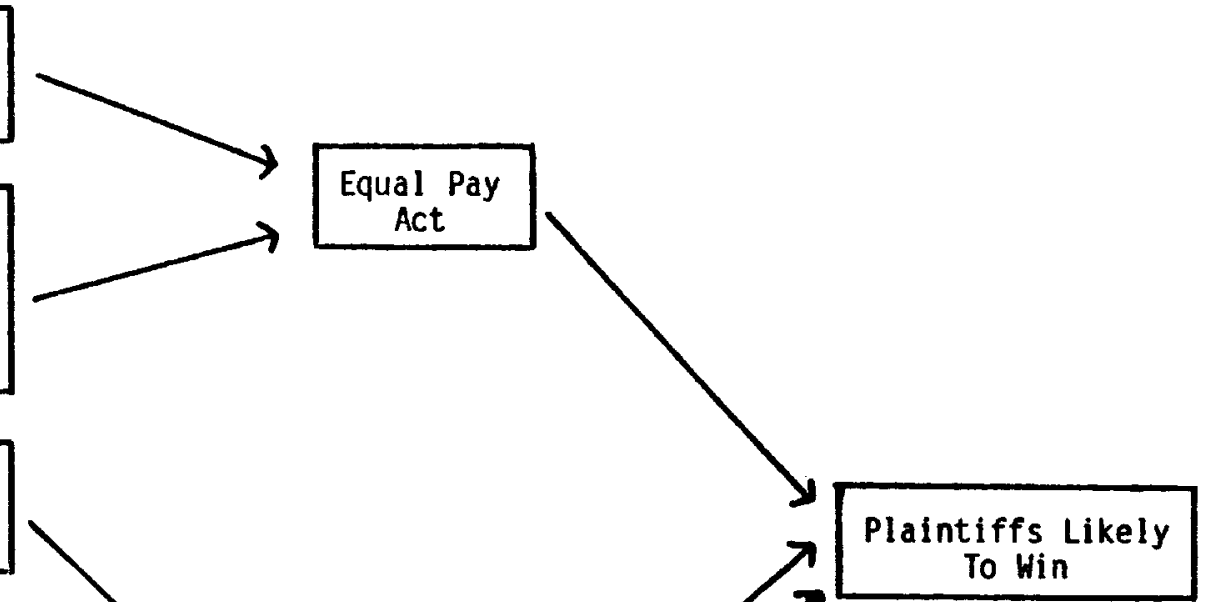

Title VII of Civil Rights Act

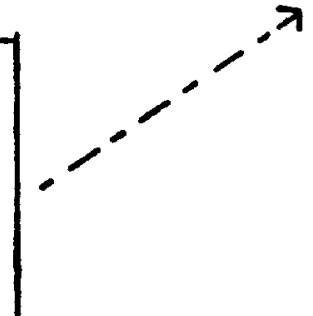

Plaintiffs Likely To Lose 
By far, the primary activity in comparable worth bargaining has been in the public sector. Examples of agreements that involve pay equity settlements include the City of San Jose and the American Federation of State, County, and Municipal Employees (AFSCME), New York State and its employee unions, the City of Los Angeles and AFSCME, and Washington State and AFSCME.

By contrast, private sector bargaining over comparable worth has been sparse. Yale University has bargained with the Hotel and Restaurant Employees International Union, AFL-CIO on this issue. The result [23] was a substantially improved wage scale for workers in female-dominated jobs, but it is not clear whether a true comparable worth settlement was reached.

American Telephone and Telegraph [20] reports the development of a form of comparable worth for twenty job categories. The company worked with its three unions to develop the plan. AT\&T claims that little undervaluing of its jobs was discovered. Changes were initially delayed because of divestiture concerns. In 1986 negotiations with the CWA and IBEW no mention was made of the issue.

A look at other recent private settlements on the national level [14] reveals nothing regarding comparable worth. Settlements in rubber, autos, steel, transportation, and the garment industry provide examples. In these and other industries, stiff foreign competition, high labor costs, and restrictive work rules have forced many unions to concentrate on cost-cutting measures and "give-backs" to preserve jobs and provide retraining for current members. In many industries male domination of unions appears to discourage support for comparable worth bargaining.

Some non-union firms [6] have also begun to experiment with forms of comparable worth. BankAmerica, Chase Manhattan Bank, IBM, Tektronix, and Motorola have all been involved. Tektronix and Motorola, both high-tech firms, report little increase in wage costs as a result of their efforts. Few of their jobs are dominated by one sex. These two companies have relied on revised job evaluation plans which cover all workers.

IBM has taken an even more direct approach by raising the wages for female-dominated jobs which are two or more standard deviations from an average wage level. Some firms, such as BankAmerica Corporation, have revised their job evaluation to put more weight of job characteristics common in jobs traditionally held by women. For example, eyestrain and muscle fatigue are among factors given additional weight.

\section{Barriers to Implementation}

As noted earlier, there is no federal court support for comparable worth at the appellate level. Without new legislation by Congress, the Supreme Court is unlikely to rule against employers in a true comparable worth dispute, And in the present political climate Congress seems unlikely to pass such legislation. 
Politics aside, the implementation of any such legislation would be extremely difficult. An administrative agency would be necessary to monitor and make rulings on pay disputes. Ultimately, the federal courts would decide many of these cases. Such dispute settlement would be much more complex than enforcement of the Equal Pay Act. It is not, therefore, surprising that Congress may avoid passing such legislation.

Outside the public sector, unions appear unlikely to demand comparable worth settlements. More pressing issues, such as job security and worker retraining, will continue to be their primary interests. Perhaps because men make up the large majority of many unions, there is often little internal political support for the issue. Also, the leadership of some unions may perceive how difficult a comparable worth settlement would be to establish and administer.

From the employer's viewpoint there can be no substitute for market realities. Without a law which requires comparable worth or a union powerful enough to insist upon it, most profit-seeking firms with large numbers of lowerpaid "female" jobs will simply be unwilling (and perhaps unable) to pay the extra wages.

And even if the employer is willing to bear this expense, the resultant web of internal relationships created among dissimilar jobs could result in great administrative problems. A change in the wage rate of any job or class of jobs could result in changes throughout the firm. If the company is dispersed geographically, the changes could become more involved and complex. If comparability is based on industry standards or other multi-firm relationships, even more complexity could be expected.

\section{Job Evaluation and Comparable Worth}

Perhaps the biggest problem with comparable worth lies in the assumption that there is a single, truly objective method for determining the worth of all of an organization's jobs. Although advocates of comparable worth are sometimes ambivalent about job evaluation, most see it as the solution to valuing dissimilar jobs. Unfortunately, job evaluation is not the objective measuring tool that we might wish it to be. Instead, it is a collection of methods that systematize judgments regarding the relative value of jobs in a job hierarchy. In truth, job evaluation can be manipulated through statistical or judgmental methods to provide varying measures of job "worth."

Most companies also use different job evaluation systems for different job families. Clerical jobs, factory jobs, and executive jobs all have separate plans. Currently, there is no widely-accepted evaluation system that covers them all.

These observations are not meant to discredit job evaluation. They simply point out its somewhat subjective nature. Job evaluation may measure what its authors set out to measure. However, it does not provide results which are independent of human design.

Indeed, job evaluation may be constructed to support or oppose adjustments to pay levels. The choice of compensable factors used, weights placed 
on each of the factors, and the number of degrees present for each factor would influence outcomes.

Suppose an employer wishes to make pay adjustments favorable to femaledominated jobs. Suppose further that a point-factor plan is being used. The employer could introduce factors found in these jobs and then weight them heavily. Examples could include eyestrain and finger dexterity for secretarial and clerical position. The total points for these jobs would increase, and their "worth" would be greater. Pricing the jobs would be done by matching them to more highly paid male-dominated jobs which are comparable in total points. Both the male and female jobs would then be paid at the higher male rates.

As our example demonstrates, job evaluation is not an objective answer to pay equity. Thus employers are likely to use it only in a way that supports their objectives in pay setting and administration. They are unlikely to agree to any evaluation system which conflicts with market realities.

\section{The Current Status of Comparable Worth}

Comparable worth has little legal vitality under our federal antidiscrimination laws. Unless Congress chooses to amend Title VII of the Civil Rights Act, comparable worth will not be an equal employment issue. At the state level, public employees have been the only beneficiaries of legislation, and this has actually occurred in only a few states so far.

Although a number of national unions and the AFL-CIO have officially endorsed comparable worth, bargaining over the issue has been sparse. Political and economic realities have no doubt dampened enthusiasm among union leaders. Where settlements in this area have occurred, they have been largely in the public sector.

A few well-known private employers have begun to implement comparable worth. In some firms the changes appear to be cosmetic since few jobs are dominated by either sex. In other instances companies with a reputation for leadership in social responsibility are apparently willing to incur extra pay costs in order to maintain this reputation. Other motives may be avoidance of public criticism or the belief that many women in their firms are really underpaid.

For the great majority of private-sector firms comparable worth has not been implemented and is not likely to be in our current legal and economic environment.

\section{Summary and Conclusions}

Comparable worth is a concept which primarily involves social judgments, not objectively measurable "truths." It can be implemented if society wants it badly enough. Its complexity, cost, and subjectivity make it unlikely to be attractive to most employers. It will not be adopted unless external forces (such as legislation or union activity) require its implementation. Thus, for 
the foreseeable future comparable worth is a policy that will not be put into effect in most organizations.

\section{References}

1. AFSCME v. State of Washington, 578 F. Supp. 846 (W.D. Wash. 1984), aff'd, 770 F.2d 1401 (9th Cir. 1985).

2. Blumrosen, Ruth G., "Wage Discrimination, Job Segregation, and Title VII of the Civil Rights Act of 1964," University of Michigan Law Review, Winter, 1980, pp. 233-301.

3. Briggs v. City of Madison, 536 F. Supp. 435 (W.D. Wis. 1982).

4. Campbell, John G., "Equal Pay for Work of Equal Value in the Federal Public Service of Canada," Compensation Review, Third Quarter, 1983, pp. 42-51.

5. Christensen v. State of Iowa, 417 F. Supp. 423 (N.D. Iowa 1976), aff'd, 563 F.2d 353 (8th Cir. 1977).

6. "Comparable Worth: It's Already Happening," Business Week, April 28, 1986, pp. 52-56.

7. Gunther v. County of Washington, 602 F.2d 882 (9th cir. 1979), rehearing denied, 623 F.2d 1303 (9th Cir. 1980), aff'd, 452 U.S. 161 (1981).

8. Gullett, C. Ray, "Comparable Worth and Pay Equity: A Challenge for Employers," Journal of Business Strategies, Vol. 1, No. 2, Fall 1984, pp. 4-14.

9. Lemons v. City and County of Denver, 17 Fair Emp. Prac. Cas. (BNA) 906 (D. Colo. 1978), aff'd, 620 F.2d 228 (10th Cir. 1980), cert. denied, 449 U.S. 888 (1980).

10. Lorber, Lawrence Z., et al., Sex and Salary, Alexandria, Va.: The ASOA Foundation, 1985.

11. Nelson, Bruce, "Wage Discrimination and the Comparable Worth Theory in Perspective," Journal of Law Reform, Winter, 1980, pp. 231-301.

12. Nelson, Bruce, "Wage Discrimination and Title VII in the 1980's: the Case Against Comparable Worth," Employee Relations Law Journal, Vol. VI, No.3, pp. 380-405.

13. Norwood, Janet L., "Perspectives on Comparable Worth," Monthly Labor Review, December, 1985, pp. 3-4.

14. Pay Equity and Comparable Worth, Washington, D.C.: Bureau of National Affairs, 1984. 
15. Rosen, Benson, et al., "Compensation, Jobs, and Gender," Harvard Business Review, July-August, 1983, pp. 170-190.

16. Spaulding v. University of Washington, 740 F.2d 686 (9th Cir. 1984), cert. denied, 469 U.S. 1036 (1984).

17. Taylor v. Charley Bros. Co., 25 Fair Emp. Prac. Cas. (BNA) 602 (W.D. Pa. 1981).

18. Thomas, Clarence, "Pay Equity and Comparable Worth," Labor Law Journal, January, 1983, pp. 3-12.

19. Treiman, Donald J. and Hartman, H.I. (eds.), Women, Work, and Wages: Equal Pay for Jobs of Equal Value, Washington, D.C.: National Academy Press, 1981.

20. Trist, C., "Pay Equity, Born in Public Sector, Emerges as an Issue in Private Firms," Wall Street Journal, July 8, 1985, p. 26.

21. U.S. Department of Labor, Time of Change: 1983 Handbook on Women Workers, Washington, D.C.: Superintendant of Documents, 1983.

22. Weiler, Paul, "The Wages of Sex: The Uses and Limits of Comparable Worth," Harvand Law Review, Vol. 99, No. 1728, pp. 1732-1743.

23. "White-Collar Unit Posts Victory in Yale Dispute," AFL-CIO News, January 26, 1985.

24. 29 U.S.C. $\$ 206(d)$

25. 42 U.S.C. $\$ \$ 2000 \mathrm{e}$ et seq. 